Supporting Information

\title{
Binder-Free, Thin-film Ceramic Coated Separators for Improved Safety of Lithium-Ion Batteries
}

\author{
Ashish Gogia ${ }^{a, b}$, *, Yuxing Wanga, *, Amarendra K. Raic, Rabi \\ Bhattacharya $^{c}$, Guru Subramanyam ${ }^{\mathrm{b}}$, Jitendra Kumar, b, *
}

a University of Dayton Research Institute, 1700 South Patterson Blvd, Dayton, $\mathrm{OH}$ 45409-7531, USA

${ }^{\mathrm{b}}$ Center of Excellence for Thin-film Research and Surface Engineering, University of Dayton, 300 College Park, Dayton, OH 45469-0232, USA

c UES, Inc., 4401 Dayton-Xenia Road, Dayton, OH 45432-1894, USA

*Corresponding Authors:

Jitendra Kumar - University of Dayton Research Institute, Dayton, Ohio 45469-7531, United States; E-mail: jitendra.kumar@udri.udayton.edu; Phone: 937-229-5314; Fax: 937-229-3873

Yuxing Wang - University of Dayton Research Institute; Dayton, Ohio 45469 -7531, United States; Email: Yuxing.wang@ud-research.org

Ashish Gogia - University of Dayton Research Institute; Dayton, Ohio 45469 -7531, United States; Email: gogiaa1@udayton.edu 


\section{Supporting Information}

Table S1. Weights and volume of the separators used in this study

\begin{tabular}{|c|c|c|c|}
\hline Separator used & Weight $\left(\mathbf{g} / \mathbf{m}^{\mathbf{2}}\right)$ & Thickness $(\boldsymbol{\mu m})$ & Volume (cm $\mathbf{3})$ \\
\hline PE & 9.96 & 12 & 0.002712 \\
\hline EB-PVD coated $\mathrm{Al}_{2} \mathrm{O}_{3}$-PE & 11.73 & 12.2 & 0.002716 \\
\hline commercial $\mathrm{Al}_{2} \mathrm{O}_{3}$-PE & 15.27 & 20 & 0.004520 \\
\hline $\mathrm{Al}_{2} \mathrm{O}_{3}$-PI & 19.25 & 22 & 0.004972 \\
\hline
\end{tabular}

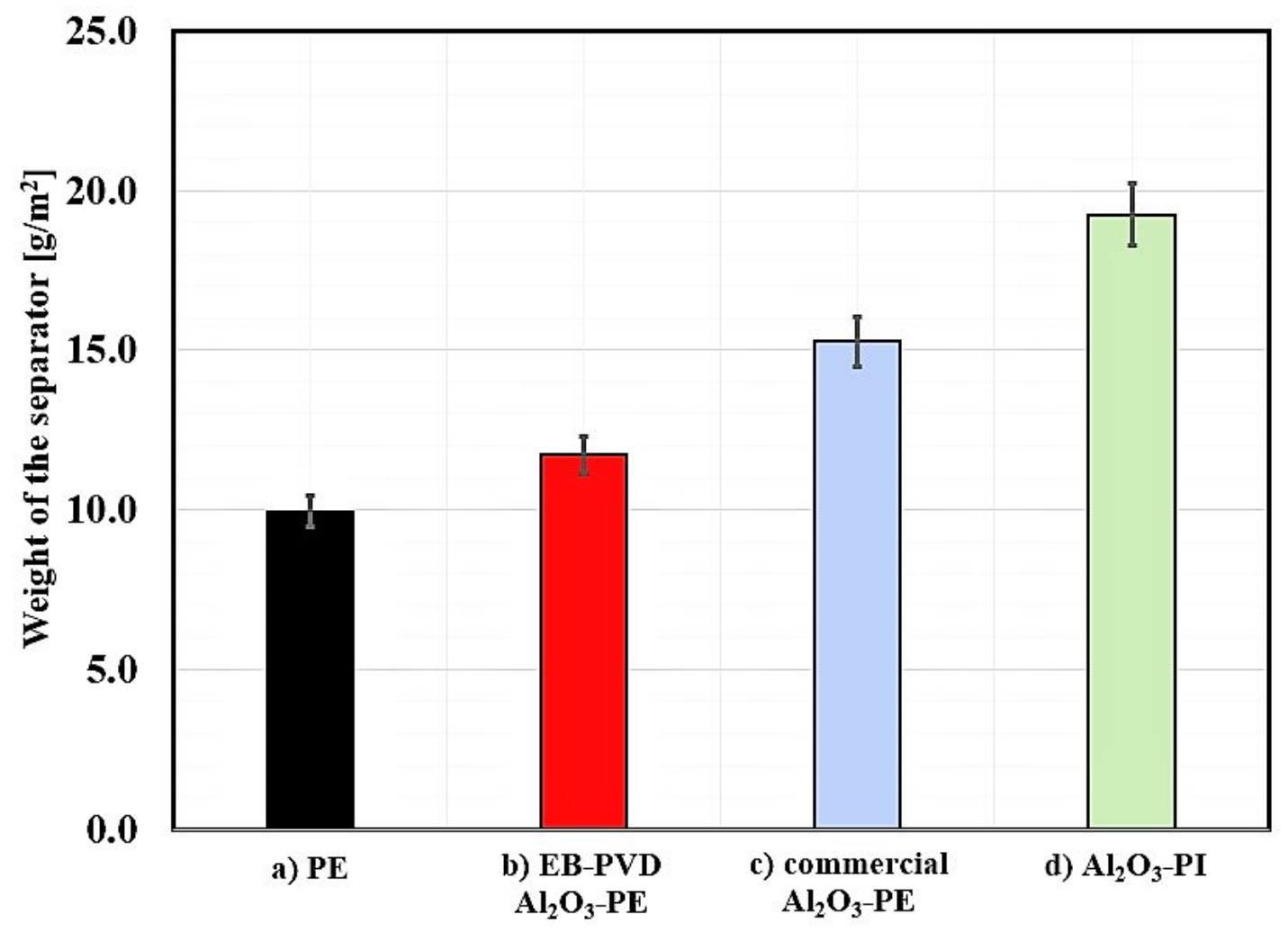

Figure S1. Weights of a) PE, b) EB-PVD coated $\mathrm{Al}_{2} \mathrm{O}_{3}-\mathrm{PE}\left(\mathrm{Al}_{2} \mathrm{O}_{3}, 100 \mathrm{~nm}\right)$, c) commercial $\mathrm{Al}_{2} \mathrm{O}_{3}$ $\mathrm{PE}\left(\mathrm{Al}_{2} \mathrm{O}_{3}, 1-2 \mu \mathrm{m}\right)$, and d) $\mathrm{Al}_{2} \mathrm{O}_{3}$-PI separator, respectively 

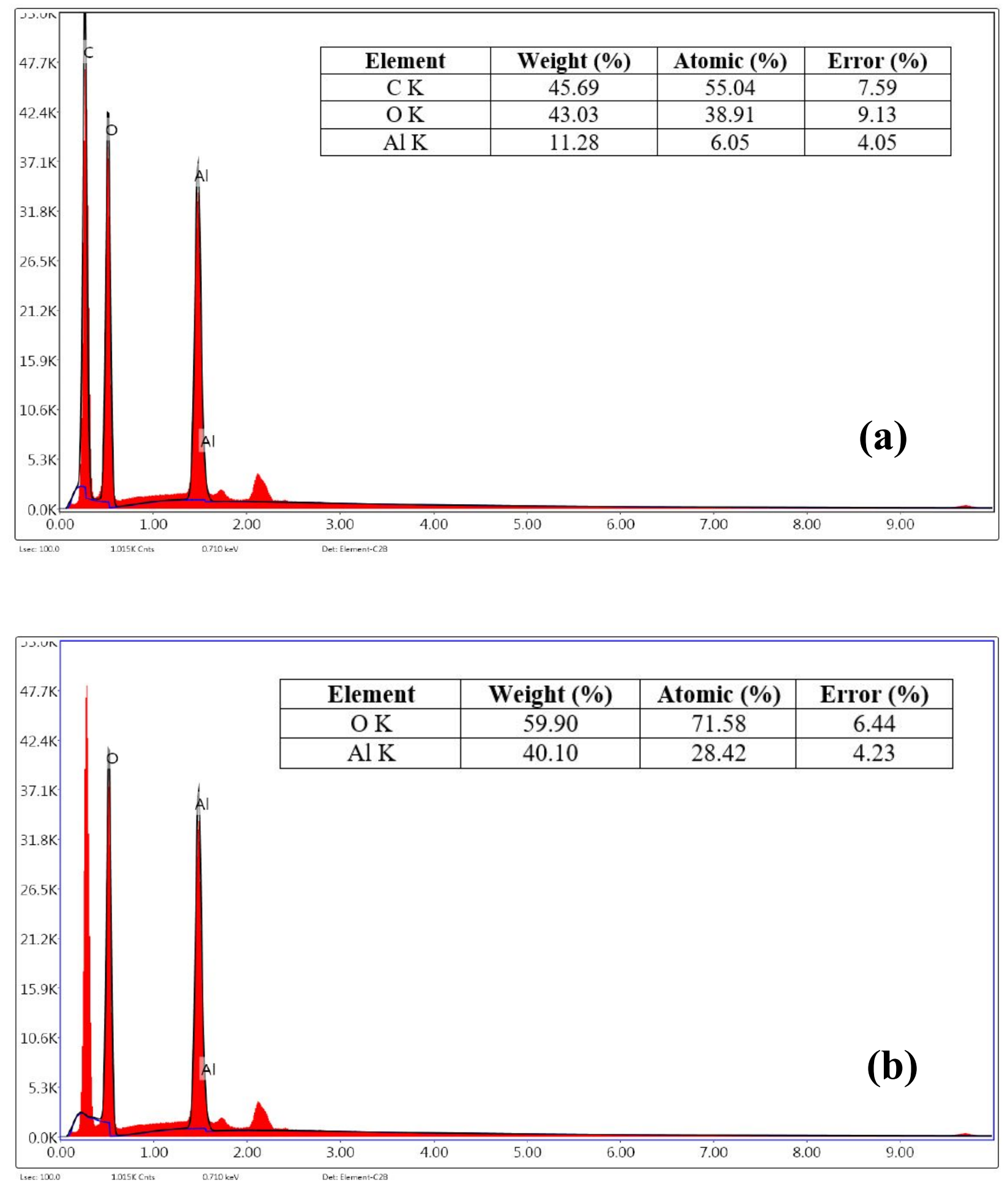

Figure S2. Energy Dispersive Spectroscopy (EDS) elemental analysis of EB-PVD coated $\mathrm{Al}_{2} \mathrm{O}_{3}$ $\operatorname{PE}\left(\mathrm{Al}_{2} \mathrm{O}_{3}, 100 \mathrm{~nm}\right)$ separator a) with carbon $(\mathrm{C})$ and, b) without $\mathrm{C}$. Elemental $\mathrm{C}$ comes from the 
polymer part of the separator. Aluminium and oxygen comes from the ceramic coating on the separator.

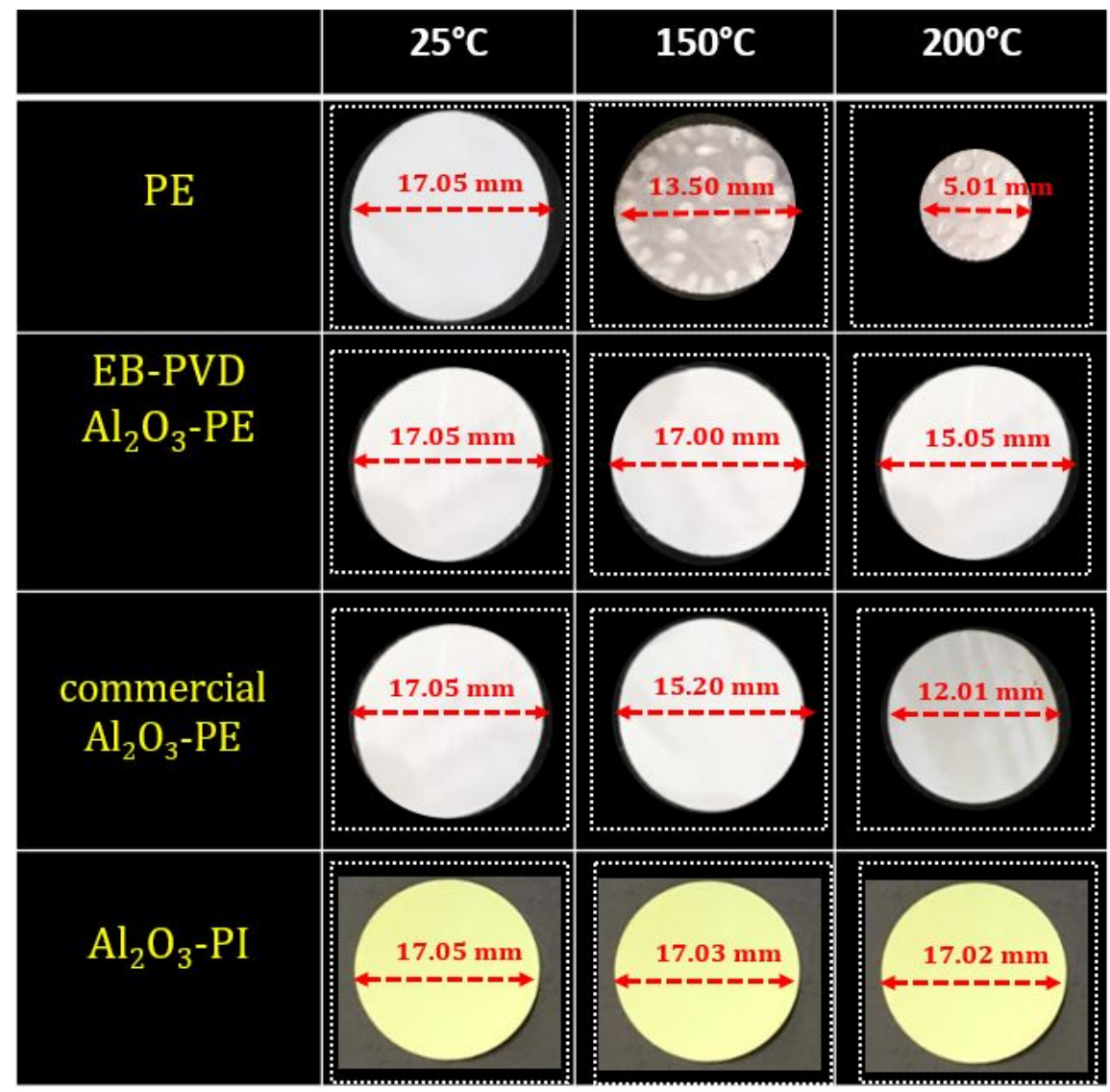

Figure S3. Thermal shrinkage measurement data comparing pristine PE, EB-PVD coated $\mathrm{Al}_{2} \mathrm{O}_{3^{-}}$ $\mathrm{PE}\left(\mathrm{Al}_{2} \mathrm{O}_{3}, 100 \mathrm{~nm}\right)$, commercial $\mathrm{Al}_{2} \mathrm{O}_{3}-\mathrm{PE}\left(\mathrm{Al}_{2} \mathrm{O}_{3}, 1-2 \mu \mathrm{m}\right)$, and $\mathrm{Al}_{2} \mathrm{O}_{3}$-PI separator before and after annealing at $150{ }^{\circ} \mathrm{C}$ and $200{ }^{\circ} \mathrm{C}$. 


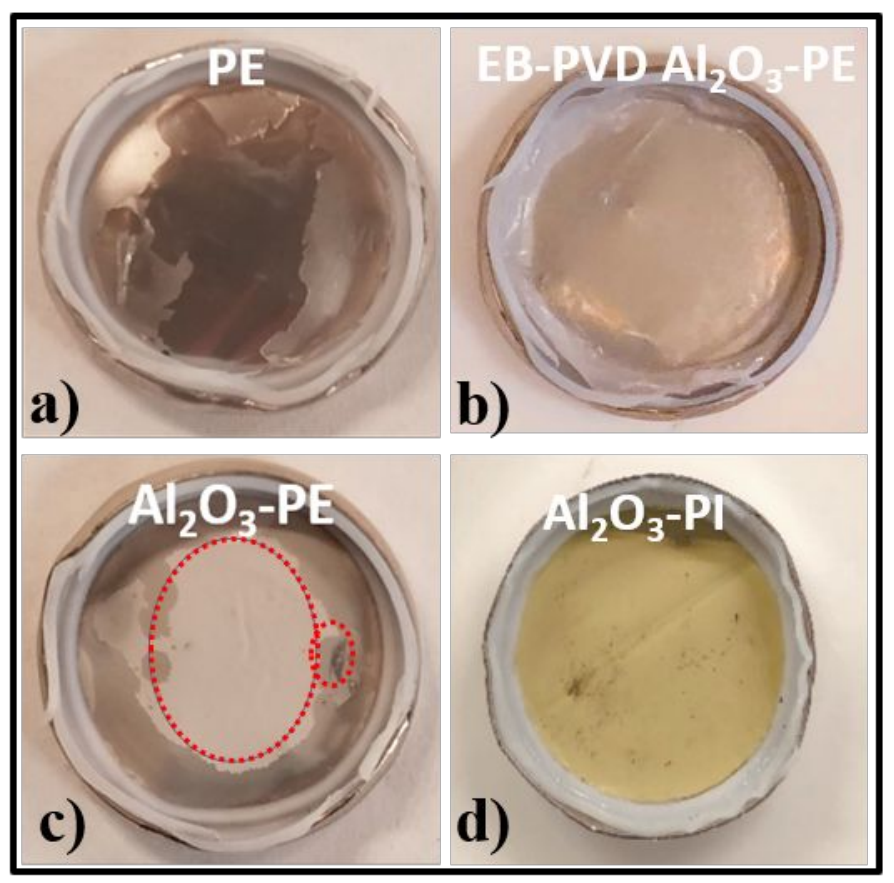

Figure S4. Postmortem optical images of a) PE, b) EB-PVD coated $\mathrm{Al}_{2} \mathrm{O}_{3}-\mathrm{PE}\left(\mathrm{Al}_{2} \mathrm{O}_{3}, 100 \mathrm{~nm}\right)$, c) commercial $\mathrm{Al}_{2} \mathrm{O}_{3}-\mathrm{PE}\left(\mathrm{Al}_{2} \mathrm{O}_{3}, 1-2 \mu \mathrm{m}\right)$, d) $\mathrm{Al}_{2} \mathrm{O}_{3}$-PI separators after in-situ impedance measurement till $190^{\circ} \mathrm{C}$.
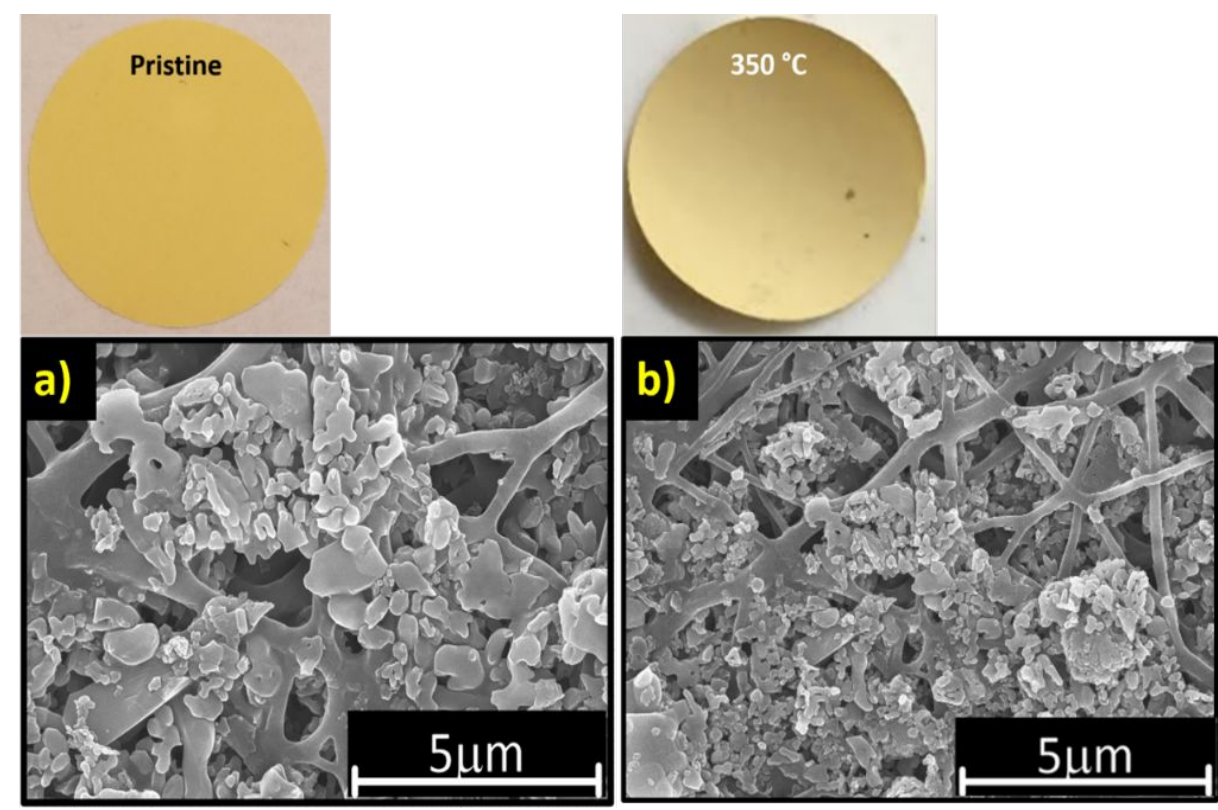

Figure S5. a) SEM morphology and optical images of $\mathrm{Al}_{2} \mathrm{O}_{3}$-PI separators a) Non-annealed, b) After annealing in argon for $1 \mathrm{~h}$ at $350^{\circ} \mathrm{C}$. 

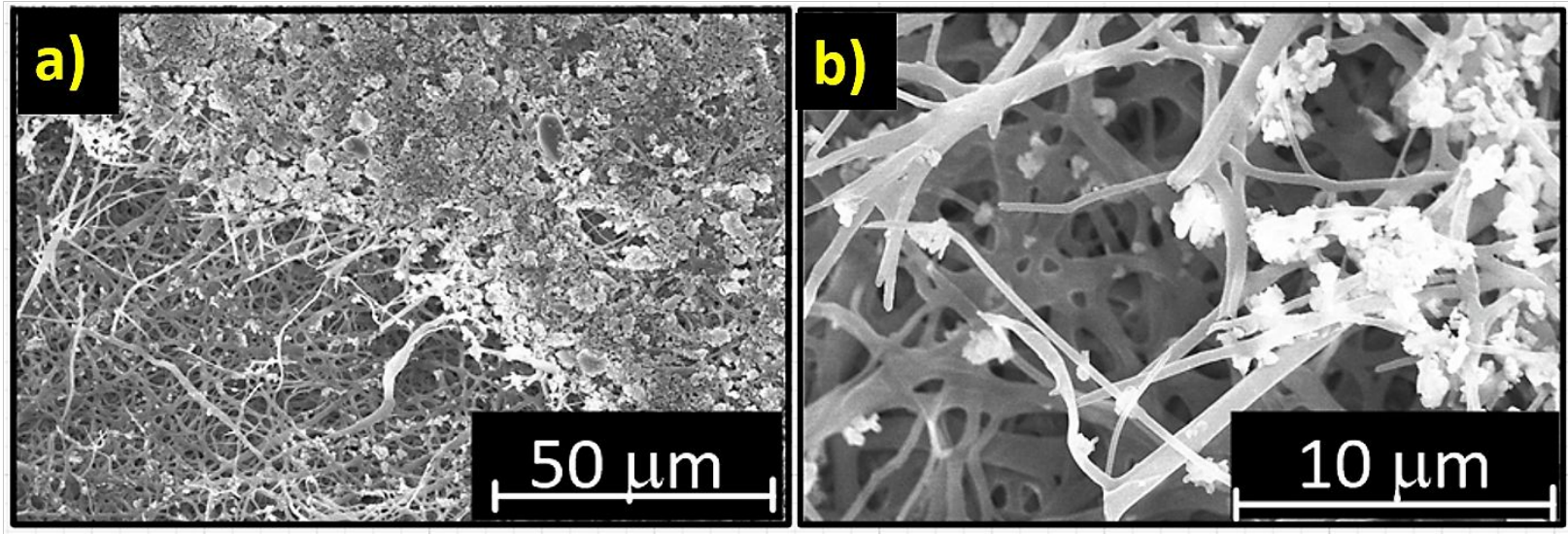

Figure S6. Morphology of the junction area (a) and tape side (b) after peeling test of the $\mathrm{Al}_{2} \mathrm{O}_{3}$-PI separator.

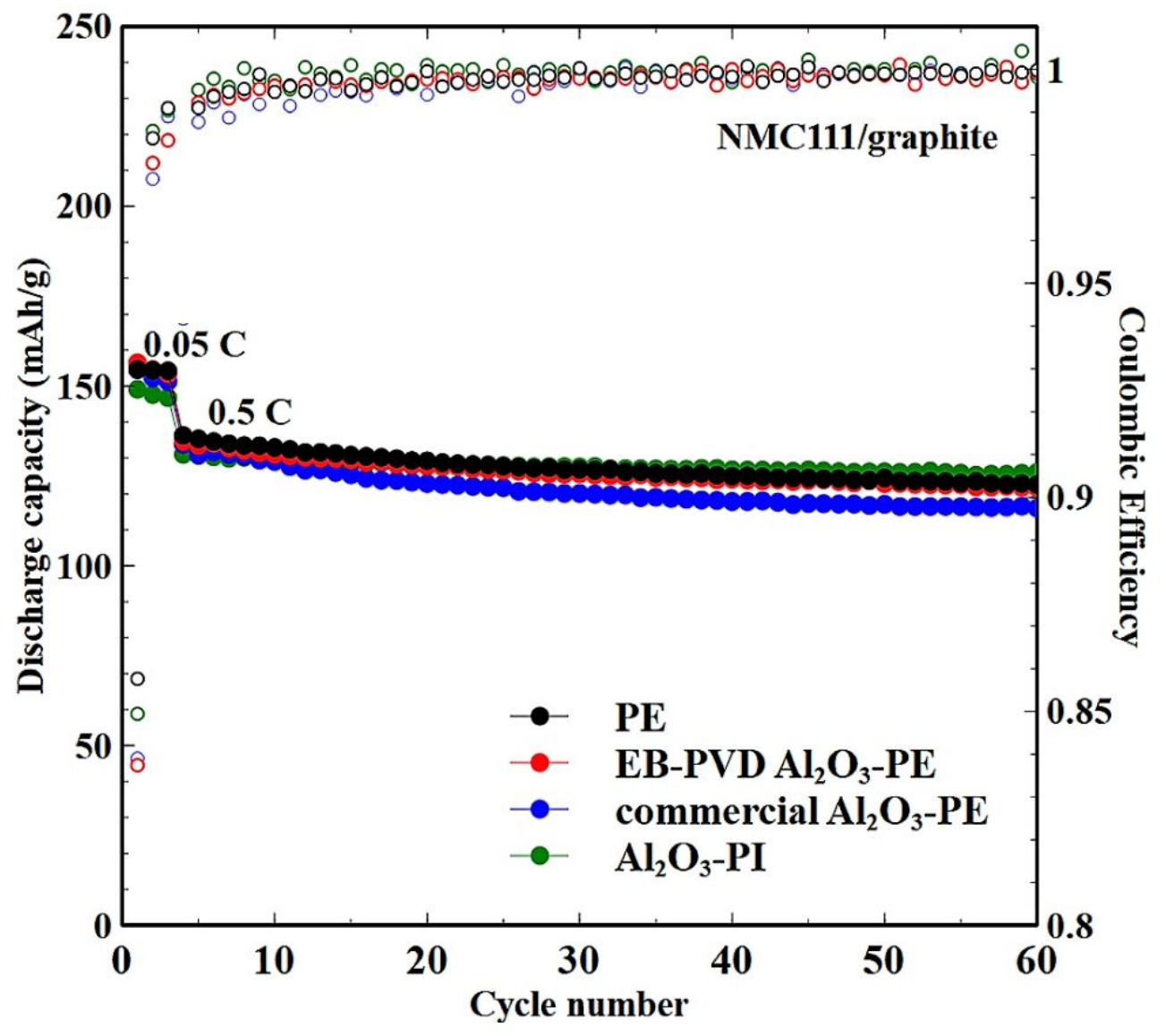

Figure S7. Electrochemical performance of NMC111/graphite full cells at $\mathrm{C} / 20(0.05 \mathrm{C}-$ Formation cycles $)$ and $\mathrm{C} / 2(0.5 \mathrm{C}$ - long term cycles $)$ using $\mathrm{PE}, \mathrm{EB}-\mathrm{PVD}$ coated $\mathrm{Al}_{2} \mathrm{O}_{3}-\mathrm{PE}\left(\mathrm{Al}_{2} \mathrm{O}_{3}\right.$, 
$100 \mathrm{~nm})$, commercial $\mathrm{Al}_{2} \mathrm{O}_{3}-\mathrm{PE}\left(\mathrm{Al}_{2} \mathrm{O}_{3}, 1-2 \mu \mathrm{m}\right)$, and $\mathrm{Al}_{2} \mathrm{O}_{3}$ coated PI separators measured at room temperature $\left(22^{\circ} \mathrm{C}\right)$.
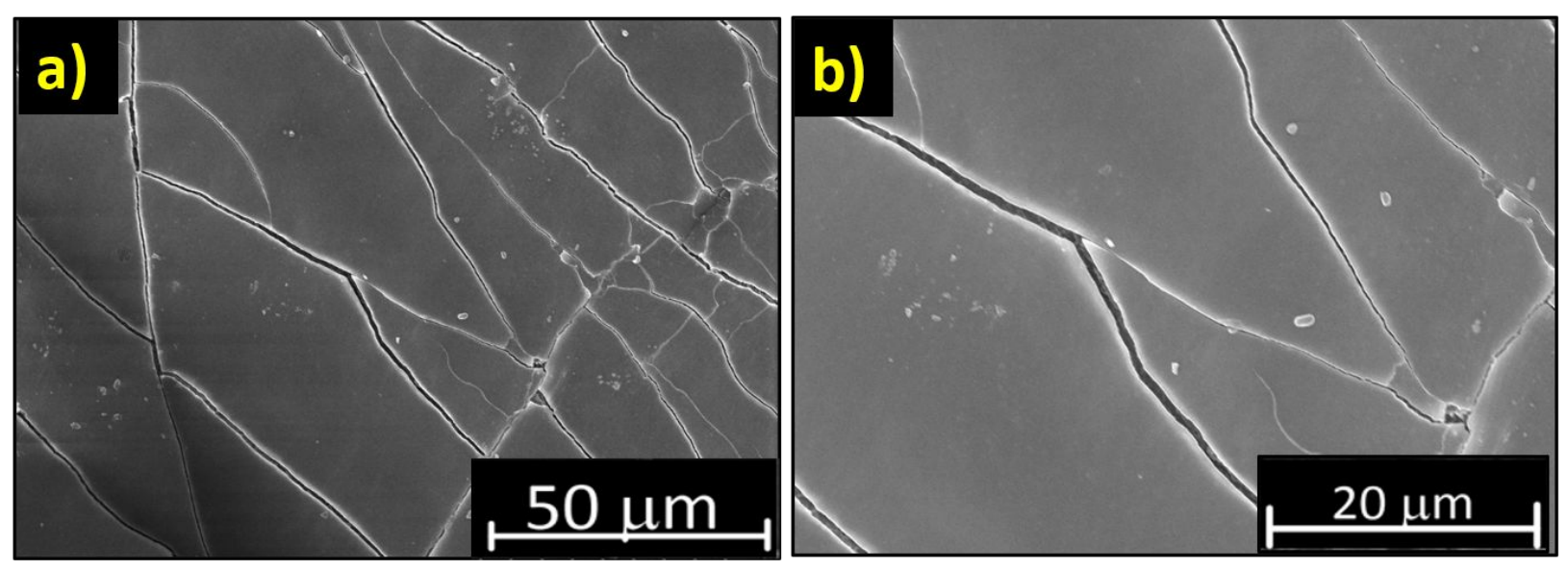

Figure S8. Separator degradation evaluation after cycling. SEM images of EB-PVD coated $\mathrm{Al}_{2} \mathrm{O}_{3}$ $\mathrm{PE}\left(\mathrm{Al}_{2} \mathrm{O}_{3}, 100 \mathrm{~nm}\right)$ separator cycled in NMC111/Graphite cells at magnifications a)1.00k, and b) $2.00 \mathrm{k}$. 


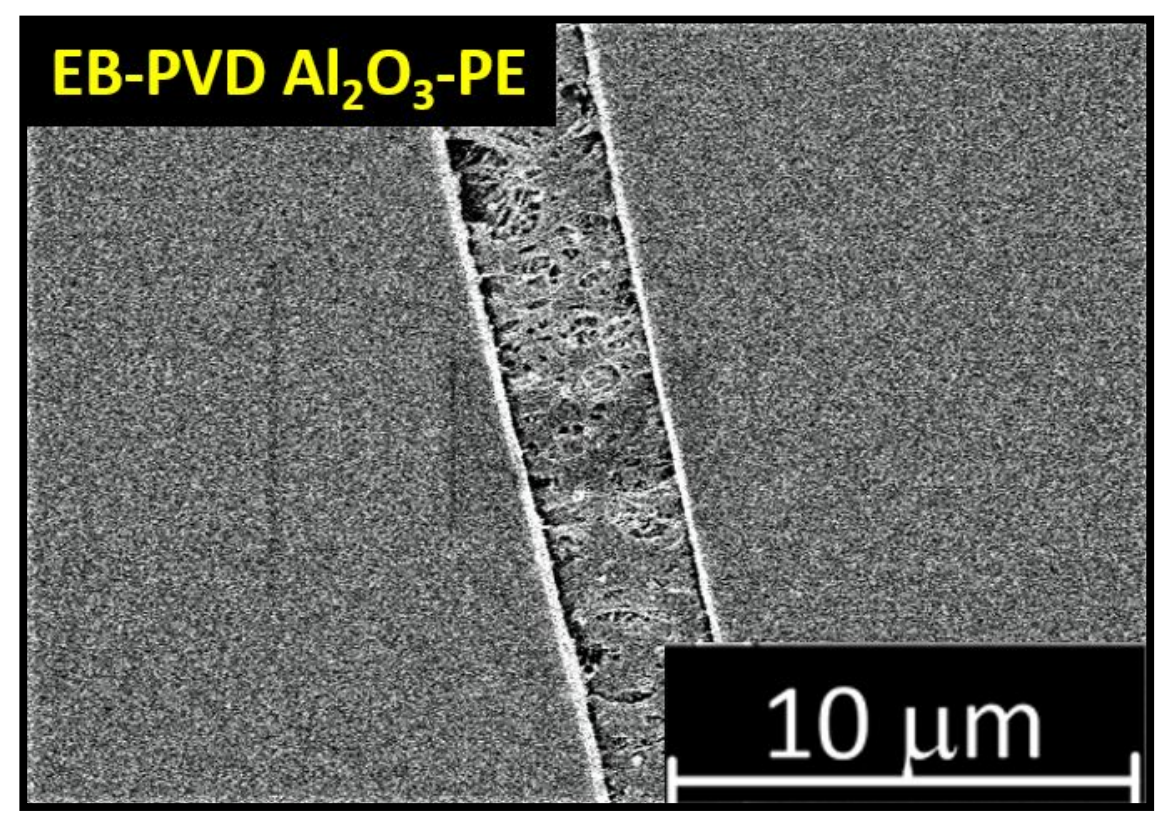

Figure S9. SEM images of EB-PVD coated $\mathrm{Al}_{2} \mathrm{O}_{3}-\mathrm{PE}\left(\mathrm{Al}_{2} \mathrm{O}_{3}, 100 \mathrm{~nm}\right)$ separator at a higher magnification. It has a dense ceramic coating. In addition to the cracks on the ceramic coating, a lot of pores are present in the polymer membrane that provides channels for $\mathrm{Li}^{+}$transport and electrolyte continuity. 